Roswitha Skare (UiT)

\title{
Nanook of the North (USA, 1922/1947/1976/1998) and Film Exhibition in the Classical Silent Era: A document unbounded?
}

\section{Introduction}

Traditional documents like printed books (independent of genre) or films (either in cinema, on television or on DVD) are usually considered as self-contained, complete units with clear borders. New media, ${ }^{i}$ often a shorthand for digital documents, on the other hand are more often discussed in terms of their complicated materiality and whether they have borders or not. The annual meetings of the Document Academy (DOCAM), an international network of scholars, artists, and professionals in various fields, who are interested in the exploration of the concept of the document, might illustrate this development. While the notion of document, different definitions and the relevance of definitions, as well as analytical concepts, and oral documents can be considered "classical DOCAM themes" (Latham \& Lund, 2014), the last two meetings have focused on Documents without Borders (2014) and Documents unbounded (2015), ${ }^{\text {ii }}$ foregrounding "the unbounded nature of new media, including social media" (Scifleet, Henninger \& Kennan, 2015). The present paper is the revised version of a presentation given at DOCAM'15, discussing the border between the inside and the outside of Robert J. Flaherty's first film Nanook of the North that premiered at the Capitol Theater in New York City in the summer of 1922. By taking Gérard Genette's concept of the paratext as point of departure and focusing on the exhibition of Nanook during the silent era, the paper discusses elements neglected in most of the academic writings about the film, thereby illustrating the highly problematic notion of film as one original or authentic document that comes as a repeatable unit with clear borders.

There are several reasons for choosing Nanook for this study: The film is one of the most seen and best-known feature films of the silent film era, "screened throughout the world, by culturally diverse audiences" (Berger, 1995, 177), thus "familiar to every school child as well as every film buff" (Shepard, 1974, 60). The film has been "widely studied and written about" (Shepard, 1974, 60), but regardless of whether the respective works focus on the relationship between fiction and truth, the features of documentary films or Flaherty's representation of the Inuit, they all speak of the film Nanook of the North, usually in combination with the year 1922. Although there have been discussions about the different 
versions of some films from the silent era, ${ }^{\text {iii }}$ the different versions of Nanook ${ }^{\text {iv }}$ and its exhibition have caused little scholarly attention so far.

But even if the different versions of Nanook would be an excellent example for discussing the importance of different paratextual elements both inside (prefaces, intertitles, the sound version's narrator, or the choice of different film music) and outside (for instance promotional material produced by Pathépicture in 1922 or by United Artists in 1947) the film, ${ }^{\mathrm{v}}$ this present article focuses on the exhibition history of Nanook, another element often neglected in the writings about the film.

\section{The exhibition of Nanook: "unitary text", text and paratext, or document complex?}

As Ross Melnick shows in his study on Samuel 'Roxy' Rothafel, motion picture exhibitors such as Roxy played an important role in the presentation and promotion of films from the silent film era (cf. also Groskopf, 2012, 84). Not only were they able to decide which films were shown; they made decisions on the film music and editing, and they incorporated individual films into a larger program. In his study, Melnick uses the term "unitary text" to discuss the "wide range of live performance and recorded media" (Melnick, 2012, 14-15) that could surround feature films during the silent era. While Melnick goes into greater detail on Roxy's program compilations for the premieres of the German movies Passion (Melnick, 2012, 191) and The Cabinet of Dr. Caligari (Melnick, 2012, 193) at the Capitol Theatre, in Nanook's case he refers primarily to elements outside the program like the Capitol's lobby:

"The unitary text of Nanook of the North was certainly not confined to the live and filmic entertainment. Audiences were immersed in the aesthetic of the film as soon as they entered the Capitol Theatre's lobby, where deerskin coats and 'Eskimo wearing apparel' were hung on the walls along with a dogsled with whips and spears." (Melnick, 2012, 202).

The term "unitary text" used by Melnick and Genette's concept of the paratext both permit the inclusion of elements outside the film text itself in an analysis. Nevertheless, I consider Genette's concept even broader than Melnick's, as it allows elements often ignored in film studies - such as intertitles, film music, opening sequences with prefaces as well as promotional material for the film - to be included. According to Genette, paratextual elements can be found both within and outside the text; they can appear and disappear at any time, and they can change position. The different modes of exhibition and the surrounding program can be considered as paratextual elements that lie somewhere in between the internal 
and the external elements of a film. These elements are particularly interesting as, on the one hand, they highlight the fact that elements of the paratext "appear at any time, $[\ldots]$ may also disappear, definitively or not" (Genette, 1997, 6) or change position, while on the other hand these are precisely the elements most often overlooked when talking about a single film like Nanook. ${ }^{\mathrm{vi}}$ In ignoring the different modes of exhibition for a silent film like Nanook, most of the writings about the film also ignore discussions in the field of film studies about films as events (cf. Gunning, 1986; Allen, 1990 and 2006) and therefore the importance of the exhibition context.

Both Melnick and Genette create new terms in order to express the complexity of their objects; both concepts include elements outside the text itself, often considered less important and therefore often neglected. But at the same time both Melnick and Genette hang on to the expression "text" when naming their concepts. This might be based on tradition - the notion of text has a strong position in both film and literary studies - or simply due to a lack of a better word. Nevertheless, one might argue that their compounds also can be considered as criticism of the notion of "text" as it is used widely in these fields. Even if the rise of new media and the emergence of new digital formats have "brought the 'materializations of the text' to the attention of literary scholars" (Brooks, 2003, 679), and literary scholars like Katherine Hayles are asking for media specific analyses (cf. Hayles, 2004), material aspects are still often considered less important than the content or the meaning of a text. While the content of a text is considered to be the product of creativity and artistry, material aspects are often regarded as craftsmanship, or as Lund puts it: "something inferior, [...] a necessary evil for symbolic production" (Lund, 2010, 736).

Lund continues the discussion of meaning versus materiality by demonstrating that scholars like Hayles, who are concerned with media specificity and thereby materiality, nevertheless only recognize physical aspects important to analyze if "they are considered important by the interpretators" (2010, 738). Lund is "not arguing for giving up the notion of text as an analytical category in all cases", but argues for the necessity "to make a critical inquiry into the possibility of developing another concept capable of dealing with coherence as well as with the diversity of media" $(2010,739)$. The concept suggested by Lund is the one of documents, defined as "any result of human efforts to tell, instruct, demonstrate, teach or produce a play, in short to document, by using some means in some ways" (Lund, 2010, 743). Using Shakespeare's Hamlet as an example, Lund argues that the written version and 
the performances should be considered different documents. Lund argues further for a complementary document theory that enables us "to study how the complexes of agents, media, and modes in practice are interacting with each other and thus how material, social and cultural options and conditions have an impact on the resulting documents" $(2010,746)$.

In the following discussion of the exhibition history of Nanook, I would like to argue that a combination of the notion of document suggested by Lund with Genette's concept of the paratext opens the floor for talking about Nanook as an unbounded document or a document complex consisting of a wide range of documents important for our understanding of the film.

\section{The exhibition of Nanook: a document unbounded?}

When we watch a film of the silent era today, we see it as an individual film; a selfcontained, complete unit. Even in the case of DVDs with extra material we see either the film or the extras. And although the user is given choices regarding the order and selection and some DVDs offer the possibility of listening to an audio commentary during the film, it is usually not possible to see the parts of a DVD as a unified program. This doubtlessly affects our reception of these films, as Stephen Bottomore shows for "all the travelogues, industrial, interest, advertising, scientific, and other films made from the 1890s" (Bottomore, 2001, 161). In rediscovering these films that were frequently forgotten in the writing of film history and screening them at film festivals according to the principal of "collecting the similar" (Bottomore, 2001, 162), we diverge increasingly from the original context in which the film was shown: "The point is", Bottomore argues, "that early cinemagoers never saw a collection of similar films screened together; they almost always saw a mixed programme" (Bottomore, 2001, 163). However, in contrast to Bottomore, who claims that this only applies to shorter films, as "each long film is more or less a programme in itself, and a modern screening is largely reproducing what audiences of the time would have seen" (Bottomore, 2001, 163), the archive material ${ }^{\mathrm{vii}}$ on the premiere of Nanook of the North shows that this was by no means the case.

Nanook premiered at the Capitol Theatre on June 11, 1922. Located in the heart of New York City on $51^{\text {st }}$ Street and Broadway (close to Times Square), the Capitol had opened in October 1919. With its 5,300 seats, it was one of the biggest cinemas in the U.S. and was classified as a deluxe first run movie theater. Since its opening on October 24, 1919, it had been managed 
by Edward Bowes; however, on June 4, 1920, Samuel Rothafel officially took over the Capitol (cf. Melnick, 2012, 188).

As a deluxe first run theater, Roxy targeted a broad, unspecified middle or even upper class audience with his shows. The design of the program for the respective show can be seen as part of this strategy. In its size and length it is reminiscent of theater programs, while at the same time it emphasizes the size and decor - and thus the significance - of the Capitol Theatre.

The film and Flaherty are presented briefly on the first inside page of the program and the production's uniqueness is pointed out. Parts of this presentation are taken from the Campaign Book for Exhibitors that was put together by Pathépicture, intending to help exhibitors advertise the film effectively.

Pages 2-4 include the order of the individual items on the program - "presented, staged and lighted by S. L. Rothafel" - while on page 5 the next week's film - The Storm directed by Reginald Barker - is announced, and page 6 provides information on emergency exits and the doctor on duty.

Image 1

Image 2

Image 3

Based on the program for the week of Nanook's showing, we can assume that the film was shown four times a day as part of a show. Both classical music - the overture of Ambroise Thomas' opera Mignon (1866) - and three different ballet numbers ("The Sugar Doll” from Tchaikovsky's Nutcracker, a Hindu dance from Léo Delibes' opera Lakmé and the "March of the Toys" from Victor Herbert's operetta Babes in Toyland), a shorter, 10-minute film, My Country (the third of the Robert C. Bruce Wilderness Tales), Tchaikovsky's Piano Concerto's First Movement, Capitol News and the aria “Ridi Pagliacci” from Ruggero Leoncavallo's opera Pagliacci are listed as six items on the program, before Nanook of the North is shown as the penultimate part of the program. Liszt's "Liebestraum" on the Capitol grand organ finishes off the show. 
Several items on the program were apparently performed at the audience's request ("Second week - By Request"), although the aria "Ridi Pagliacci" was only included in three of the four performances. Apart from Nanook, the length of the individual program items varies between five and fifteen minutes. The Capitol News at fifteen minutes is according to the program:

"An institutional compilation of items of pictoral news of the week edited from a standpoint of entertainment and general interest with a psychological arrangement of its salient features and so interpreted by orchestral and other effects as to make it one of the finest magazine units of its kind."

This was by no means a feature unique to the New York Capitol, but was quite common in so-called deluxe first run movie theaters between 1911 and 1931, as can be seen from Harold B. Franklin's guidelines:

"On its program will be found a feature, which consists of five to seven reels of a thousand feet of film each; a number of short subjects, generally comprising a one- or two-reel comedy, and a news weekly; or sometimes a travel scenic or other novelty subject. In larger cities, there may be also one or more of the following stage presentations: a revue, a prologue inspired by the feature, a dance divertissement, soloists, or some number specially produced by the management. Frequently, well-known actors or actresses appear before the patrons of a De Luxe Theater" (Franklin, 1928, 116).

If we consider the theater building with its luxurious decorations, the printed program as well as the different posts on the program as paratextual elements of the film, their importance in framing the viewing experience becomes clear; or as Genette points out, the paratext "is at the service of a better reception for the text and a more pertinent reading of it (more pertinent, of course, in the eyes of the author and his allies)" (Genette, 1997, 2).

The different program posts of the show presented by Roxy are surrounding Nanook, thus framing and introducing the film to the audience. Classical music, ballet numbers, news, and a short film together with a feature film not only provided the viewer with 'good value' in relation to the ticket price, they also set the tone for how to view and understand the film. Well-known classical tunes by composers like Tchaikovsky and Liszt might have been what the audience expected during the summer of 1922, but they also familiarize the exotic and far away content of the film for the audience. The program surrounding the film, together with the Capitol's size and decor, and the choice of films were all components intending to prove 
that films could be "much more than just a lowbrow divertissement" (Melnick, 2003, 65) for the masses.

If we look at the different program posts as different documents, we might argue that these documents together form the document complex Nanook of the North at the Capitol Theater during the week of its premiere in June 1922. The fact that the aria "Ridi Pagliacci" was not a part of all performances illustrates the changing size of this document complex. Other elements like the objects in the lobby, the printed program itself, together with promotional materials produced by Pathépicture like the Campaign Bookfor Exhibitors or the newspaper look-alikes Pathé Sun and Photoplay Sidelights presenting the film in text and image to potential exhibitors, could also be included into this document complex. The border between the inside and the outside can at least be described as blurred; what documents can be found in different archives will push the border in one way or another, as does the researcher's focus.

Considering the fact that many patrons did not come solely for the feature film (cf. Bachman, 1997, 31), but for the "spectacular event" (Jones, 2012, 7), one might even argue that the show presented at the Capitol can be considered as one document, Nanook being only one part of it. But it is in fact Nanook that is the main focus of the reviews following the premiere. Only a few reviews mention the program surrounding the film by listing the individual items, such as the review in the New York Morning Telegraph of June 12, 1922:

“'My Country,' that fine Robert C. Bruce wilderness tale, remains for another Capitol week. Juan Reyes, Chilean pianist, and Louis Dornay, Dutch tenor, contribute several fine musical numbers. The ballet selections include those old favorites. Victor Herbert's 'March of the Toys' and the Nutcracker Suite of Tschaikowsky. Doris Niles appears in an original Hindu dance. The overture is 'Mignon'. (Sexton, 1922)

Only a comparison with other programs at the Capitol and their reviews - of an entire season, for example - would reveal the extent to which it was common to focus the review on the film and what the possible causes for this might be. In the case of the program under discussion here, we can only assume that the audience was familiar with the "old favorites" and they needed no separate presentation or recommendation, while the film was a novelty for its theme and location alone. 
As mentioned earlier, the aria "Ridi Pagliacci" was, according to the printed program, only included in three of the four performances, making the performance at $4 \mathrm{p} . \mathrm{m}$. shorter than the other three. At the same time, we know nothing about how the shows differed on each day or in the week of the premiere, and to what extent - if any - changes were made in response to the audience's reactions. Many questions, for example whether the entire orchestra was present for all performances or not, must remain unanswered. For in actual fact, for the Capitol alone we are speaking here of 21 performances over the course of a week. Even if we do not have any sources documenting these different performances, it is not unreasonable to expect that they were not identical, but in fact different documents with some similarities and some differences.

But the viewing of Nanook as part of a larger live performance is by no means a boundary for the document complex of Nanook; the paratext doesn't stop here. According to Genette, the elements of the paratext can be divided into peritext and epitext, depending on their location in relation to the text/film itself. The question then is whether the theater building and the printed program, together with decorations in the Capitol lobby and in the windows of nearby stores (cf. Melnick, 2012, 202f) should be considered inside or outside the film. This is not an easy question to answer, especially if we consider that these elements can change their location at a later point: "The ways and means of the paratext change continually, depending on period, culture, genre, author, work, and edition, with varying degrees of pressure, sometimes widely varying: [...]" (Genette, 1997, 3).

In addition to the already mentioned elements that might influence the audiences' viewing of the film, we can find many more elements outside the film: "The distanced elements are all those messages that, at least originally, are located outside the book, generally with the help of other media [...] or under cover of private communications [...]" (Genette, 1997, 5). In the case of Nanook these are for instance materials produced by Pathépicture to promote the film, but also the knowledge the audience had about Flaherty's background as an explorer in the Arctic regions during the 1910 s.

The Campaign Bookfor Exhibitors, a booklet that collects different material supposed to help the exhibitor to promote the film, consists of 16 pages and presents the film in text and image. Catch-lines like "Distinctive!" and "Different!" are suggested together with many superlatives like "the truest and most thrilling story" or "Newer than New, Greater than 
Great, More Dramatic than Drama, [...]" promising the exhibitor that the audience will "see it again and again" and "talk about it forever". On the front page one of the available ads is used, presenting us for the film's title and subtitle, the names of Flaherty, Revillon Frères, and Pathépicture. The image used, presents us for Nanook in struggle with a dog.

In order to attract the attention of the audience and to make them talk about the film, several concrete suggestions under the title "Ideas, Stunts and Bally-hoo" are presented on page 3: The focus is on the exotic otherness ("Get the Eskimo atmosphere. Build an igloo over your box office."; "Dress a man like an Eskimo"), but also on elements familiar to a Western audience ("Emphasize the human angle, life, love, battle mother love and dreams."). Exhibitors are advised to use "The four column ad of the front cover of the campaign book" in big spaces. They are also encouraged to repeat this advertisement because "[r]epetition makes reputation”.

As mentioned before, Roxy actually used suggestions from the Campaign Book for his presentation of Flaherty and Nanook in the program, and for the decoration of the lobby, thus transferring paratextual elements from the outside into a much closer relationship with the film and its exhibition. The case of Nanook's premiere at the Capitol thereby also demonstrates the fact that other persons than Flaherty were involved in the process and had huge influence on how the film was presented to the audience.

In addition to these materials, also Flaherty's own writings about his expeditions and his filmmaking, as well as publications by Révillon Frères like Eskimo life of yesterday (1922) were used to promote the film and to give the potential audience an idea about what to expect. Film reviews in newspapers, and film critics and theorists' writing about Flaherty and the film makes the list even longer, and shows the difficulty of where to draw the line in an analysis of the film. What has to be included, what could be ignored; what would be inside and outside our document Nanook of the North?

As Genette points out, "one must resist the temptation to enlarge" the transitional zone between text and beyond-text, "be wary of rashly proclaiming that 'all is paratext"' (Genette, 1997, 407). But as long as these elements are providing "some commentary on the text and influence how the text is received" (Genette, 1997, 7), these elements are important for our understanding of the film, both as a historical document and as a piece of art. Especially in 
the case of Flaherty's Nanook and its position in film history as first documentary, the focus on the film's actuality and on Flaherty's explorations in the Arctic is to be taken into account. Even if the audience of 1922 was not familiar with all these elements, they will have had some knowledge about Flaherty and the film and thereby certain expectations. As Genette points out, people do not need to "know those facts; I am saying only that people who do know them read Proust's work differently from people who do not and that anyone who denies the difference is pulling our leg" (Genette, 1997, 8). A closer look at the later editions of the film reveal that the missing historical context of the 1922 film viewing is replaced by different forewords (cf. Skare, 2010). But even if these forewords differ in length, they all provide the audiences with information about Flaherty, focusing on the film's authenticity, and thereby guiding the viewer's attention in a certain direction.

\section{Nanook after its premiere at the Capitol}

Although the archive material on Nanook is very extensive and includes information on when, where and how the film was shown after the premiere, no complete picture of its exhibition history emerges. On the one hand, apart from a few exceptions the material is limited to the English-speaking world; on the other, the collection seems to be dependent on what material Flaherty was sent by cinema operators and other individuals and what was collected by a press clipping bureau. Furthermore, not all newspaper articles are dated precisely and some only have partial source references, so that it can be difficult to place the information both geographically and chronologically. Nevertheless, the material shows how difficult it is to speak of the performance of Nanook and its reception in general terms.

Only a week after its premiere at the Capitol, the film was shown at the Rye Playhouse - a cinema with around 650 seats - in Rye, NY. This event is well documented by the cinema's two-week program (June 12 to June 24) as well as the program for the two days that Nanook was shown. A glance at the films of these two weeks reveals that films were shown either on a single day or on two consecutive days.

Image 4

Nanook was screened twice daily (matinee and evening) on June 21 and 22, 1922. Flaherty's "short talk each evening" is presented as a "great added privilege". The fact that Nanook was shown on two consecutive days in a total four performances without a second film indicates 
the film's special prominence and the success anticipated. The film is presented as a "special" and announced with the subheading "A Story of the Far North, Photographed in the Heart of the Hudson Bay territory, The most remarkable and unusual picture ever produced, Grand opening at the Capitol Theatre, New York, June, 12, 1922.” A longer text also presents Flaherty and announces his presence at the evening performances. As far as can be told from the program, the film was not presented as part of a larger program, and only the evening viewings with Flaherty's "short talk" formed a larger unit. Presumably the Rye Playhouse had neither a large orchestra nor dancers, as no live performances are listed among the advertised items on the program. Nevertheless, Flaherty's presence can be seen as a paratextual element, giving the audience an opportunity to experience the explorer and filmmaker in person. We can at least assume that Flaherty's presence provided the screening of the film with an aura of authenticity. Even if his talk is not passed down, we can suppose that he might have talked about his many trips to the Arctic and the making of the film, as he did in his writings. Thereby making it even more believable for the audience that they were watching pictures from the real Arctic.

At the same time as Nanook was presented as part of a larger unit at both deluxe first run cinemas and smaller theatres, the film also got presented as a double feature, as we can see from The Pathe Sun of June 10, 1922 that quotes branch manager Coughlin, Dallas, on Nanook. Coughlin reports that "Southern Enterprises expect to play it with 'A Sailor-Made Man'.” Also a letter from N.J. Moors to Flaherty, dated Ululaloa, November 25, 1923 confirms the same trend. Moors writes about Nanook's success and that the film was shown alongside Wanted A Husband. According to Moors, however, "the crowd came chiefly to see Nanook". To which extent Nanook's popularity was supposed to gain an audience for the respective other film in the double feature or whether the aim was simply to attract as many viewers as possible using the bargain principle, remains unclear. However, the examples cited here show clearly that double features did not become common only during the years of the Great Depression, and that film screenings in the classic silent film era were by no means identical. From the projection speed to the film music to the film as part of a program and the material/advertisements surrounding the film both inside and outside the cinema, the size of the cinema, national and regional particularities - these and other factors influenced the way in which the respective audience experienced the film. These factors also support the argument of talking about Nanook as an unbounded document, not only when discussing the different versions of the film, but also its exhibition history. 


\section{Conclusion}

More a "one-time performance" (Hansen, 1991, 93) than identical repetition of the film is one argument for talking about Nanook as a document unbounded. Considering the fact that the different parts of that performance could change from performance to performance, from theater to theater, from town to town, and from country to country makes that argument even stronger. For in actual fact, for the Capitol alone we are speaking here of 21 performances or 21 documents that might differ from each other over the course of a week.

Genette's concept of the paratext provides a tool to handle the fluid character of these performances and makes us conscious about the complexity of elements both outside and inside the document and on the border between the inside and the outside and their importance for the reception of a document. Where to draw the line for an analysis will often depend on what we consider as the document and its parts. In Documentation Studies the concept of the paratext provides us with a terminology that allows us to place and name elements of a document belonging to its materiality. As shown in this paper, material elements of course have influence on how a document's meaning is perceived by the audience; material aspects have to be analyzed together with social and mental aspects in order to achieve a proper understanding of the document. One might argue that a document in combination with its paratext creates a document complex. At the same time both Genette's concept and the notion of a document complex is not completely unproblematic. Not only the existence and availability of archival material, but also decisions made by the researcher will be important for the outcome. As shown in this paper, many questions have to remain unanswered even if there is a huge amount of archival material as in the case of Nanook.

The context of a film performance has changed so much for today's audience - not the least in regard to their experience and expectations of films - that it is impossible to reconstruct the 1922 version. Even if we assume that David Shepard did the best possible job in restoring Nanook, using all materials available by that time from archives around the world, and that the restored version is "a Nanook whose visual composition, timing and sequence match as closely as possible the original film" (Dobi, 1977, 8), we also have to admit that the paratextual elements surrounding the film's premiere are impossible to reconstruct. Even if a screening at a theater with over 5.000 seats could be arranged, and Roxy's program performed by dancers, singers, and a large orchestra, today's audience would of course be a 
totally different one than in 1922 and experience both the film and the surrounding program on the background of today's knowledge and expectations.

Films from the classical silent film era therefore are excellent examples for documents unbounded. Talking about Nanook of the North as an unbounded document heightens our attention to different versions and editions and makes us conscious about the highly problematic notion of one original or authentic film version. At the same time the notion of an unbounded document and the use of Genette's concept of the paratext uncovers new questions, as for instance how to decide what elements to include in an analysis and what elements that can be ignored. But even if we decide to draw the line by the film 'itself', we still have to consider different prefaces, different musical scores, and different modes of exhibition.

Even if Nanook of the North in many aspects is exceptional because of the archival situation, its existence in different versions on different platforms, etc., I would like to argue that the existence of film in several versions is more typical than atypical, especially when we are talking about film from the silent era and the importance of the exhibitor as a kind of coproducer. New technological possibilities could be used to make the film in different versions with different musical scores, and together with surrounding promotional materials available for today's audience, not pretending to present the original but rather call the audience's attention to the variations between the documents.

\section{References}

Allen, R.C. (1990), "From exhibition to reception: reflections on the audience in film history", Screen 31.4, pp. 347-356.

Allen, R.C. (2006), "Relocating American Film History”, Cultural Studies 20.1, pp. 48-88.

Bachman, G. (1997), "Still in the Dark - Silent Film Audiences”, Film History 9.1, pp. 23-48. Berger, S. (1995), "Move over Nanook". Wide Angle. A Film Quarterly of Theory, Criticism and Practice 17.1, pp. 177-191.

Bottomore, St. (2001), “Rediscovering Early Non-Fiction Film”, Film History 13.2, pp. 160173. 
Brooks, D.A. (2003), “Gadamer and the Mechanics of Culture”, Poetics Today 24.4, pp. 673694.

“Campaign Book for Exhibitors", Studies in Visual Communication 6.2 (Summer 1980), pp. $61-76$.

Dobi, St. (1977), “Restoring Robert Flaherty's Nanook of the North”, Film Library Quarterly 10.1/2, pp. 6-17.

Franklin, H.B. (1928), "Motion Picture Theater Managment (1928)", Moviegoing in America. A sourcebook in the History of Film Exhibition, ed. by Gregory A. Waller (2002), Oxford, Blackwell Publishers, pp. 116-123.

Friedberg, A. (2000), “The End of Cinema: Multimedia and Technological Change”, Christine Gledhill and Linda Williams (eds.), Reinventing Film Studies, London, Arnold, pp. 438-452.

Genette, G. (1997), Paratexts. Thresholds of Interpretation. Cambridge, Cambridge University Press.

Groskopf, J. (2012), "Profit Margins: Silent Era Precursors of Online Advertising Tactics", Film History 24.1, pp. 82-96.

Gunning, Tom (1986), “The Cinema of Attractions: Early Film, Its Spectator and the AvantGarde", Wide Angle 8.3\&4, pp. 63-70.

Hansen, M. (1991), Babel \& Babylon. Spectatorship in American Silent Film, Cambridge and London, Harvard University Press.

Hayles, N.K. (2004), "Print is flat, code is deep: the importance of media-specific analysis", Poetics Today 25.1, pp. 67-90.

Jones, J. (2012), The past is a moving picture. Preserving the twentieth century on film. Gainesville, University Press of Florida.

Latham, K.L. \& Lund, N.W. (2014), "Editorial Welcome to the Inaugural Volume”, Proceedings from the 11th Annual Meeting of the Document Academy, ideaexchange.uakron.edu/docam/vol1/iss1/ (accessed March 29, 2016).

Lund, N.W. (2010), "Document, text and medium: concepts, theories and disciplines", Journal of Documentation, 66.5, pp. 734 - 749.

Melnick, R. (2003), “Rethinking Rothafel: Roxy’s Forgotten Legacy”, The Moving Image 3.2, pp. 62-95.

Melnick, R. (2012), American Showman. Samuel 'Roxy' Rothafel and the Birth of the Entertainment Industry, New York, Columbia University Press. 
Musser, Ch. (1991), Before the Nickelodeon. Edwin S. Porter and the Edison Manufacturing Company, Berkeley, University of California Press.

Pingree, G.B. \& Gitelman, L. (2003), “Introduction: What's New About New Media?”, in Gitelman, L. \& Pingree, G. B. (Ed.), New Media 1740-1915, Cambridge, MA and London, The MIT Press, pp. xi-xxii.

Rotha, P. \& Ruby, J. (1983), Robert J. Flaherty. A Biography, Philadelphia, University of Pennsylvanias Press.

Sciflet, P., Henninger, M. \& Kennan, M.A. (2015), "Guest Editorial Note”, Proceedings from the 12th Annual Meeting of the Document Academy, ideaexchange.uakron.edu/docam/vol2/iss1/ (accessed March 29, 2016). Sexton, S. (1922), "Eskimo starred at the Capitol”, The Morning Telegraph, New York, June 12.

Shepard, D. (1974), "Letters. To the Editor”, Film Comment 10.2, pp. 59-60.

Skare, R. (2010), "Nanook of the North (1922) - Zur Rolle paratextueller Elemente für das Verständnis des Films”, Neohelicon 37, pp. 231-246.

Skare, R. (2016), “Nanook of the North” From 1922 to Today. The Famous Arctic

Documentary and its Afterlife, Frankfurt/M., Peter Lang (forthcoming).

\footnotetext{
${ }^{i}$ For a discussion of the use of terms like old and new media cf. Pingree \& Gitelman, 2003, pp. xi-xxii. As they point out, old media "were not always old", "[a]ll media were once 'new media"" (xi).

${ }^{\text {ii }} \mathrm{Cf}$. http://ideaexchange.uakron.edu/docam/ for the proceedings.

iii Cf. for instance Musser, 1991, 230-233 about the differences between two prints of The Life of An American Fireman (1903), focusing on the textual variations inside the film.

iv Dobi, 1977 mentions the sound version and the restoration of the film by International Film Seminars during the 1970s. Cf. also Rotha \& Ruby, 1983, 295-296.

${ }^{v}$ For a detailed discussion of these elements cf. Skare, 2016.

vi There are of course film scholars engaged with the changes that cinema underwent since its invention and especially in the digital age (cf. Friedberg, 2010), but we also have to bear in mind that cinema itself has undergone tremendous changes during the 20th century that influence our experience of a film on the screen. Today, it is hard to imagine what it would be like to watch a film together with several thousand other spectators at one of those large first-run deluxe theatres of the 1920s.

vii In addition to the Robert Joseph Flaherty papers (1884-1970) located in the Butler Library of Columbia University in NYC other institutions such as the New York Public Library for the Performing Arts also hold material such as scrapbooks on the Capitol Theatre and on Samuel 'Roxy' Rothafel. As far as this material touches on Flaherty and Nanook, it is more or less identical with the material of the Flaherty archive at Columbia. Many of the trade journals where Pathépicture advertised Nanook in 1922 are also available online at the Media History Digital Library.
} 